JAMA 1968;206: 1255-7.

${ }^{2}$ Richter RW, Pearson J. Heroin addiction related neurological disorders. In: Medical Aspects of Drug Abuse. Hagerstown, Maryland: Harper and Row, 1975:320-37.

${ }^{3}$ Ell JJ, Uttley D, Silver JR. Acute myelopathy in association with heroin addiction. $J$ Neurol Neurosurg Psychiatry 1981;44: 448-50.

${ }^{4}$ Loizou LA, Boddie HG. Polyradiculoneuropathy associated with heroin abuse. J Neurol Neurosurg Psychiatry 1978;41:855-7.

${ }^{5}$ Richter RW, Challenor YB, Pearson J, Kagen LJ, Hamilton LL, Ramsey WH. Acute myoglobinuria associated with heroin addiction. JAMA 1971;216:1172-6.

\section{Plaques and tangles and transmitter deficiencies in dementia}

Sir: In Alzheimer type dementia there is a degeneration and loss of the central noradrenergic neurons of the locus caeruleus ${ }^{1-3}$ associated with which are reductions in brain noradrenaline concentration ${ }^{145}$ and dopamine $\beta$ hydroxylase activity, ${ }^{6}$ together with decreased 3-methoxy-4-hydroxyphenyl levels in both brain ${ }^{7}$ and urine. ${ }^{8}$ Recent reports $^{37}$ suggest that within the broad spectrum of patients with Alzheimer type dementia, there exist subgroups, characterised by either a severe, or a milder loss, of neurons from the locus caeruleus. Furthermore, a more severe dementia and an earlier death have both been noted in those cases where cell loss is extreme, ${ }^{3}$ though these differences are not seemingly associated with extra reduction in dopamine $\beta$-hydroxylase activity or 3-methoxy-4-hydroxyphenyl glycol levels. ${ }^{7}$ This apparent anomaly is explained by the occurrence, in these more severely affected cases, of a possible compensatory ingrowth of nora drenergic fibres from areas other than the locus caeruleus, in response to the more extensive loss of these latter cells.
Other studies, ${ }^{5}$ report that noradrenaline concentration is also reduced in patients with Down's syndrome, when the Alzheimer type of pathology is present, and suggest that loss of noradrenergic activity is a feature specific to Alzheimer type dementia.

We have investigated the brains of patients with Alzheimer type dementia, in whom there were variable losses of locus caeruleus neurons, for evidence that extra impairment of function may occur in those cases where cell loss was more severe. We have also examined for changes in locus caeruleus neurons the brain of a patient with Down's syndrome, and the brains of retired professional boxers with dementia pugilistica, in which the extensive neurofibrillary degeneration of nerve cells, in contrast to Alzheimer type dementia is not accompanied by significant senile plaque formation.

Brains were obtained from 19 cases of Alzheimer type dementia (mean age 84.7 $\pm 1 \cdot 1$ years) one case of Down's syndrome (age 59 years) and from four retired boxers (mean age $56.5 \pm 1.3$ years). Two separate groups of patients, matched for age and sex, and dying free of neurological or psychiatric disease, were controls and these totalled 21 patients (mean age $85 \cdot 1 \pm 1 \cdot 1$ years) and 16 patients (mean age 55.9 \pm 1.3 years) respectively. The number of nucleolated nerve cells per $20 \mu \mathrm{m}$ section was counted $^{2}$ and the volume of the nucleolus in remaining nerve cells was measured, ${ }^{1}$ in the locus caeruleus, on both sides, in all 60 cases. Statistical comparisons were made using Student $\mathbf{t}$ test.

Overall, the mean number of nucleolated nerve cells in the 19 cases of Alzheimer type dementia (Group 3) was reduced by $55 \%$, and the nucleolar volume of residual cells was also significantly reduced by $20 \%$, when compared with values from the control group (table). Values of cell number and nucleolar volume in those cases of Alzheimer type dementia where counts of locus caeruleus nerve cells fell below 30 per section (Group 1) were analysed separately from the remaining cases (Group 2), where such counts exceeded this figure (table). The only significant difference found between the two groups was in cell counts. Therefore, it seems that, in both Alzheimer type dementia groups, the capacity of remaining cells to form proteins is equally reduced, irrespective of the actual number of cells that are still present. Categorisation of Alzheimer type dementia cases into subgroups, based on changes in cell number in locus caeruleus alone is arbitrary since reductions in functional integrity of the locus caeruleus cell group are probably, therefore, more closely related to changes in function within individual cells rather than decreases per $s e$ in overall cell number. It is probably for this reason, rather than compensatory ingrowth, that similar dopamine- $\beta$-hydroxylase and 3-methoxy-4-hydroxy-phenyl glycol values were recorded by Perry and colleagues, ${ }^{7}$ in both their subgroups.

In the Down's syndrome case there was virtually a complete loss of nerve cells from the locus caeruleus and the few that remained (numbering 4.6 per $20 \mu \mathrm{m}$ section; about $5 \%$ of control number of 90.8$)$ contained large globose neurofibrillary tangles. Nucleolar volume, in these residual cells, was reduced by $28 \%$, from $\mathrm{a}_{\overline{\mathrm{C}}}$ control value of $69 \cdot 1 \mu \mathrm{m}^{3}$ to one of $49.9 \supseteq$ $\mu \mathrm{m}^{3}$. Decreases in brain concentration of noradrenaline in Down's syndrome ${ }^{5}$ would seem, therefore, to be due to loss and atrophy of cells in the locus caeruleus, as is the case in Alzheimer type dementia.

In the four cases of dementia puglistica the mean number of nerve cells in the locus caeruleus was $29.8 \pm 1 \cdot 7$, which was significantly less $(p<0.001)$ than the 90.8 \pm 1.4 counted in the control group. Nucleolar volume in the remaining cells was

Table Changes in locus caeruleus nerve cells in Alzheimer type dementia: mean \pm sem

\begin{tabular}{|c|c|c|c|c|}
\hline & \multirow[b]{2}{*}{ Normal $(n=21)$} & \multicolumn{3}{|c|}{ Alzheimer type dementia } \\
\hline & & Group $1(n=9)$ & Group $2(n=10)$ & Group $3(n=19)$ \\
\hline $\begin{array}{l}\text { Locus caeruleus } \\
\text { neuron numbers } \\
\text { (Mean/20 } \mu \mathrm{m} \text { section } \\
\text { Nucleolar volume }\left(\mu \mathrm{m}^{3}\right) \\
\text { Brain weight }(\mathrm{g}) \\
\text { Sexes } \mathrm{M} \\
\text { Age at death }(\mathrm{yr})\end{array}$ & $\begin{array}{r}75 \cdot 8 \pm 3 \cdot 2 \\
69 \cdot 9 \pm 1 \cdot 0 \\
1205 \cdot 2 \pm 25 \cdot 2 \\
6 \\
15 \\
85 \cdot 1 \pm 1 \cdot 1\end{array}$ & $\begin{aligned} 21.9 & \pm 1.9^{*} \\
55.3 & \pm 2.6^{*} \\
1137.2 & \pm 38.7 \\
2 & \\
7 & \\
83.9 & \pm 1.8\end{aligned}$ & $\begin{aligned} 45 \cdot 4 & \pm 4 \cdot 7^{*} \\
57 \cdot 8 & \pm 2 \cdot 5^{*} \\
1160 \cdot 8 & \pm 1 \cdot 2 \\
5 & \\
5 & \\
85 \cdot 8 & \pm 1 \cdot 2\end{aligned}$ & $\begin{aligned} 34.3 & \pm 3.8^{*} \\
56.6 & \pm 1.8^{*} \\
1149.6 & \pm 24.7 \\
7 & \\
12 & \\
84.7 & \pm 1.1\end{aligned}$ \\
\hline
\end{tabular}

*Significantly (Student $t$ test) different from normal at $\mathrm{p}<0.001$. The only significant difference between group 1 and group 2 cases of Alzheimer type dementia was between locus caeruleus counts $(p<0.001)$. 
$51.2 \pm 1.4 \mu^{3}$, which was also significantly less $(p<0.001)$ than that of $69.1 \pm 1.3 \mu \mathrm{m}^{3}$ measured in the controls. Reductions in nerve cell number and nucleolar volume of $67 \%$ and $26 \%$ respectively, are similar to these decreases in Alzheimer type dementia and Down's syndrome and may be presumed, therefore, to lead to substantial depletion of brain noradrenaline in this condition also.

It therefore seems that loss of noradrenergic activity is found in all those dementias characterised by a neurofibrillary degeneration of nerve cells even though senile plaques may not always be present. The alterations in protein synthesis that lead to formation of paired helical filaments have been related to the presence of toxic substances, particularly aluminium, ${ }^{9}$ within the brain, which may accumulate from an altered permeability of the microvasculature, stemming from loss of modulation by noradrenergic fibres ${ }^{10}$. Changes in cholinergic activity, similar to those in Alzheimer type dementia, ${ }^{11}$ and Down's syndrome, ${ }^{12}$ occur in scrapie, ${ }^{13}$ a slow virus disease affecting sheep and goats, in which amyloid plaques, similar to senile plaques, but not neurofibrillary changes, are present in the brain. ${ }^{14}$ This suggests that alterations in the cholinergic rather than noradrenergic neurotransmitter system may be fundamental to plaque formation in ATD and Down's syndrome, a conclusion strengthened by the close quantitative relationship ${ }^{15}$ that occurs between reductions in choline acetyl transferase activity and frequency of senile plaques in cases of Alzheimer type dementia.

DMA MANN

PO YATES

J HAWKES

Department of Pathology,

The University,

Manchester M13 9PT, UK

\section{References}

' Mann DMA, Lincoln J, Yates PO, Stamp JE, Toper S. Changes in the monoamine containing neurones of the human CNS in senile dementia. $\mathrm{Br} J$ Psychiat 1980;136:533-41.

${ }^{2}$ Tomlinson BE, Irving D, Blessed G. Cell loss in the locus caeruleus in senile dementia of Alzheimer type. J Neurol Sci 1981;49:419-28.

${ }^{3}$ Bondareff W, Mountjoy CQ, Roth M. Selective loss of neurones of origin of adrenergic projection to cerebral cortex (nucleus locus caeruleus) in senile dementia. Lancet $1981 ; \mathbf{i}: 783-4$.

4 Adolfsson R, Gottfries CG, Roos BE, Winblad B. Changes in brain catecholamines in patients with dementia of Alzheimer type. Br J Psychiat 1979;135:216-23.

${ }^{5}$ Yates CM, Ritchie IM, Simpson J, Maloney AFJ, Gordon A. Noradrenaline in Alzheimer-type dementia and Down's syndrome. Lancet 1981;ii:39-40.

${ }^{6}$ Cross AJ, Crow TJ, Perry EK, Perry RH, Blessed G, Tomlinson BE. Reduced dopamine- $\beta$-hydroxylase activity in Alzheimer's disease. Br Med J 1981;1:934.

${ }^{7}$ Perry EK, Tomlinson BE, Blessed G, Perry RH, Cross AJ, Crow TJ. Noradrenergic and cholinergic systems in senile dementia of Alzheimer type. Lancet $1981 ;$ ii: 149.

${ }^{8}$ Mann DMA, Lincoln J, Yates PO, Brennan CM. Monoamine metabolism in Down's syndrome. Lancet 1980;ii:1365-6.

9 Crapper DR, Quittkat S, Krishnan SS, Dalton AJ, De Boni U. Intranuclear aluminium content in Alzheimer's disease, dialysis encephalopathy and experimental aluminium encephalopathy. Acta Neuropathol (Berl) 1980;50:19-24.

${ }^{10}$ Raichle ME, Hartman BK, Eichling JO, Sharpe LG. Central noradrenergic regulation of cerebral bloodflow and vascular permeability. Proc Nat Acad Sci USA 1975;72:3726-30.

"Perry EK, Gibson PH, Blessed G, Perry RH, Tomlinson BE. Neurotransmitter enzyme abnormalities in senile dementia. $J$ Neurol Sci 1977;34:247-65.

12 Yates CM, Simpson J, Maloney AFJ, Gordon A, Reid AH. Alzheimer-like cholinergic deficiency in Down's syndrome. Lancet 1980;ii: 979.

${ }^{13}$ McDermott JR, Fraser H, Dickinson AG. Reduced choline acetyl transferase activity in scrapie mouse brain. Lancet 1978;ii:318-9.

${ }^{14}$ Bruce ME, Fraser $\mathrm{H}$. Amyloid plaques in the brains of mice infected with scrapie. Neuropath Appl Neurobiol 1975;1:189202.

${ }^{15}$ Perry EK, Tomlinson BE, Blessed G, Bergmann K, Gibson PH, Perry RH. Correlation of cholinergic abnormalities with senile plaques and mental test scores in senile dementia. Br Med J 1978;2:1457-9.

Progressive spastic paraplegia due to persistent echo virus encephalomyelitis in a child with $\mathbf{X}$-linked hypogamma globulinaemia

Sir: We wish to describe a boy who presented with signs of a progressive spastic paraplegia and was found to suffer from hypogammaglobulinaemia and chronic encephalitis due to Echo virus type 29 Intact $\mathrm{T}$ cell function was indicated by the lymphocytic infiltrates in the CNS and by lymph nodes depleted of lymphocytes and with absent reactive follicles in the vestigial germinal centres. Although there was no family history in our patient, his age, sex and persistent encephalitis suggest the $\mathrm{X}$-linked form of hypogammaglobulinaemia. The particular points of interest in this case are absence of frequent infections and preservation of normal intelligence.

A 16-months-old boy was admitted with increased tone in his limbs and brisk tendon reflexes. He had lost his motor skills from the age of 12 months when he was noticed to cease walking and after the age of 14 months he was no longer able to sit without support. He was born to healthy unrelated parents at term following a normal pregnancy. Birth weight was $3290 \mathrm{~g}$. The neonatal period was normal. His early developmental milestones were normal; he sat unsupported at 6 months, pulled to stand at 9 months and walked holding on at 10 months. He began to speak at 12 months and progress of his mental development continued unimpaired. Except for a febrile illness with erythematous rash and vomiting at the age of 3 months he did not have any other illnesses.

Investigations at the age of 16 months were normal for blood count (leucocytes 9.6 $\times 10^{\circ} / 1$, neutrophils $41 \%$, lymphocytes $57 \%$, monocytes $2 \%$ ), liver function, urate, blood and urine amino and organic acids, blood lactate and pyruvate and lysosomal $\mathbb{D}$ enzymes. Computed tomography of the brain and myelography showed no abnormality. The CSF contained $0.010 \times 10^{9} / 1$ white blood cells with $80 \%$ lymphocytes, ()$\cdot 1$ $\mathrm{g} / \mathrm{l}$ protein and normal glucose. Enterovirus was isolated from the CSF.

The child had another febrile illness with a rash at 17 months and died at 20 months from fulminant Pseudomonas aeruginosa septicaemia with purulent cholecystitis. At necropsy apart from cholecystitis the most important finding was in the CNS. The brain was normal in size and outward appearance but slight opacity of the meninges was noted. On coronal sectioning the only abnormality was slight enlargement of the lateral ventricles. Histological examination revealed slight to moderate lymphocytic infiltration of the cerebral and spinal meninges. Perivascular lymphocytic cuffs (fig A) were present in all regions of the cerebrum, brain stem, cerebellum and spinal cord. The infiltration was extensive but the individual cuffs were thin. In addition a moderate degree of microglial proliferation with nodule formation (fig B) was seen in the optic nerves, hypothalamus, thalamus, brain stem, cerebellum and spinal cord Neuronal degeneration was less obvious in the cerebral and cerebellar hemispheres but more pronounced in the brain stem, where in addition to the colliculi nuclei pontis and 